\begin{tabular}{|l|l|l||}
\hline \multicolumn{2}{|c|}{ PublisherInfo } \\
\hline \hline PublisherName & $:$ & BioMed Central \\
\hline \hline PublisherLocation & $:$ & London \\
\hline \hline PublisherImprintName & $:$ & BioMed Central \\
\hline \hline
\end{tabular}

\title{
Retroviral risk
}

\begin{tabular}{|l|c|l||}
\hline \multicolumn{2}{|c|}{ ArticleInfo } \\
\hline \hline ArticleID & $:$ & 4458 \\
\hline \hline ArticleDOI & $:$ & $10.1186 /$ gb-spotlight-20020423-01 \\
\hline \hline ArticleCitationID & $:$ & spotlight-20020423-01 \\
\hline \hline ArticleSequenceNumber & $:$ & 124 \\
\hline \hline ArticleCategory & $:$ & Research news \\
\hline ArticleFirstPage & $:$ & 1 \\
\hline \hline ArticleLastPage & $:$ & 2 \\
\hline \hline & & RegistrationDate : 2002-4-23 \\
\hline ArticleHistory & $:$ & OnlineDate \\
\hline \hline ArticleCopyright & $:$ & BioMed Central Ltd2002-4-23 \\
\hline \hline ArticleGrants & $:$ & \\
\hline \hline ArticleContext & $:$ & 130593311 \\
\hline \hline
\end{tabular}




\section{Jonathan B Weitzman}

Email: jonathanweitzman@hotmail.com

Gene therapy strategies have been riddled with technical problems and much-publicized risks. In the April 19 Science, Li et al. deal another blow to gene therapy (Science 2002, 296:497). They found that when they used replication-defective retroviruses to deliver a marker gene to mouse bone marrow cells, the animals developed leukemia. Li et al. transplanted the bone marrow cells into irradiated recipients; all these animals developed hematopoietic disorders after six months. All the diseased mice had the same leukemic clone with a single integrated vector copy. The insertion event induced expression of the Evil gene, encoding a transcription factor linked to acute myeloid leukemia. The authors suggest that the marker transgene may also contribute to tumor formation. The risk of cancer is yet another factor that must be considered in future gene therapy trials.

\section{References}

1. Science, [http://www.sciencemag.org]

2. Influence of multiplicity of infection and protein stability on retroviral vector-mediated gene expression in hematopoietic cells. 